\title{
The effect of different oils and diets on total gas production in an artificial rumen (Rusitec)*
}

\author{
D. Jalč' , A. Cieślak ${ }^{2}$, M. Szumacher-Strabel², A. Potkański \\ and J. Kowalczyk ${ }^{3}$ \\ ${ }^{1}$ Institute of Animal Physiology, Slovak Academy of Sciences \\ Soltesovej 4-6, 04001 Košice, Slovak Republic \\ ${ }^{2}$ The August Cieszkowski Agricultural University of Poznań, \\ Department of Animal Nutrition and Feed Management \\ Wotyńska 33, 60-637 Poznań, Poland \\ ${ }^{3}$ The Kielanowski Institute of Animal Physiology and Nutrition, Polish Academy of Sciences \\ 05-110 Jabtonna, Poland
}

\begin{abstract}
Four experiments were carried out in a Rusitec system. The effect of different diets $(100 \%$ fresh lucerne, experiment I; $60 \%$ fresh lucerne $+40 \%$ maize, experiment II; $40 \%$ fresh lucerne $+60 \%$ maize, experiment III) and fat sources (linseed oil-LO, rapeseed oil-RO, fish oil- FO, 5\%wt.wt ${ }^{-1}$ ) on gas production and hydrogen balance was studied. In experiment IV the basic diet composition was as in experiment II but the diets were supplemented with $5 \%$ wt. $^{-1} \mathrm{t}^{-1}$ of oil blends: $\mathrm{LO}+\mathrm{RO}, \mathrm{LO}+\mathrm{FO}$ or $\mathrm{LO}+\mathrm{FO}+\mathrm{RO}$. A significant $(\mathrm{P}>0.05)$ reduction in the total gas production was noticed only in the full forage diets supplemented with LO, RO and FO.
\end{abstract}

KEY WORDS: in vitro, lucerne, maize, oils, total gas, hydrogen

\section{INTRODUCTION}

In some developed countries special emphasis is placed on reduction of environmental degradation associated with animal production. Scientists have recently been searching for a new in vitro method that would reflect the feed fermentation profile in the rumen. Total gas production in vitro appears to be a potentially useful marker of feed component digestibility, e.g., starch fermentation (Chai et al., 2004). It is also possible to examine the effects of various fat types on in vitro gas production and diet digestibility (Getachew et al., 2001). The objective of the present study was to compare diets comprising three different fresh lucerne-

\footnotetext{
"Supported by the Grant Agency of the Slovak Academy of Sciences, Grant No. 2/6174/6 and the State Committee for Scientific Research (Poland), Grant No. 3 P06Z 05923

1 Corresponding author: e-mail: jalcd@saske.sk
} 
to-maize ratios in diets supplemented with rapeseed, linseed or fish oils and their blends on total gas production in a Rusitec system.

\section{MATERIAL AND METHODS}

The rumen simulation technique was employed to test different types of diets (forage, forage:concentrate 60:40 or 40:60) and 5\% wt.wt ${ }^{-1}$ of oils (rapeseed $\mathrm{RO}$, linseed LO, or fish oils FO) on total gas production and hydrogen balance. Details of the method were previously described by Jalč et al. (2006a). On days 8-13 gas samples were collected and the total volume was measured by a gasmeter. Production, utilization and recovery of metabolic hydrogen were calculated according to the stoichiometry of rumen fermentation as suggested by Demeyer (1991). The following equations were used:

a. production of metabolic $\mathrm{H}_{2}=2 \mathrm{~A}+\mathrm{P}+4 \mathrm{~B}+2 \mathrm{iV}+2 \mathrm{~V}\left(\mathrm{mM} \mathrm{day}^{-1}\right)$

b. utilization of metabolic $\mathrm{H}_{2}=2 \mathrm{P}+2 \mathrm{~B}+4 \mathrm{M}+\mathrm{V}\left(\mathrm{mM} \mathrm{day}^{-1}\right)$

c. recovery of metabolic hydrogen $=\mathrm{H}_{2}$ utilization $/ \mathrm{H}_{2}$ production $\times 100(\%)$,

where $\mathrm{A}, \mathrm{P}, \mathrm{B}, \mathrm{V}, \mathrm{iV}$ and $\mathrm{M}$ are the molar amounts of acetate, propionate, n-butyrate, valerate, isovalerate, and methane, respectively.

All data were analysed using one-way analysis of variance (ANOVA) and compared by the Tukey-Kramer multiple comparison test.

\section{RESULTS AND DISCUSSION}

The primary gaseous end product of fermentation is carbon dioxide and onethird of this is reduced to methane (Czerkawski, 1986). The gas mixture in the rumen consists largely of carbon dioxide $(65 \%)$ and methane $(26-27 \%)$. Some nitrogen $(7 \%)$, traces of oxygen $(0.5 \%)$ and some hydrogen $(0.2 \%)$ may be also present. The amount of produced gas is proportional in volume to volatile fatty acid production, thereby serving as an indicator of volatile fatty acids produced by fermentation. In experiment I, total gas production was significantly $(\mathrm{P}<0.05)$ suppressed by oil supplementation to a forage diet (Table 1). In contrast, supplementation of oils and oil blends to high-forage (experiments II, IV) or high concentrate (experiment III) diets did not affect total gas production. Similar results were obtained by Getachew et al. (2001) when saturated fats (tallow or yellow grease) were tested. In the same study, however, potassium soaps of maize oil, tallow and yellow grease depressed gas production in vitro. The authors suggested that triglycerides have a much smaller effect on rumen fermentation parameters than the corresponding free fatty acids. On the other hand, oils rich in unsaturated fatty acids (e.g., maize oil) may stimulate elevated gas production in comparison with oils rich in saturated fatty acids (Getachew et al., 2001).

Although hydrogen is one of the major end products of fermentation in protozoa, fungi, and pure monocultures of some bacteria, it is not accumulated in the rumen, because it is immediately used by other bacteria present in the mixed microbial ecosystem. Metabolic hydrogen in the form of reduced protons $(\mathrm{H})$ can 
Table 1. Effect of different oils and their blends supplemented to diets on gas production in Rusitec (n-6)

\begin{tabular}{|c|c|c|c|c|c|}
\hline \multirow{2}{*}{ Items } & \multicolumn{5}{|c|}{ Added oil $\left(5 \% \mathrm{wt} \cdot \mathrm{wt}^{-1}\right)$} \\
\hline & control $^{\mathrm{a}}$ & $\mathrm{LO}^{\mathrm{b}}$ & $\mathrm{RO}^{\mathrm{c}}$ & $\mathrm{FO}^{\mathrm{d}}$ & pooled \pm SEM \\
\hline & \multicolumn{5}{|c|}{ 100\% fresh lucerne (experiment I) } \\
\hline $\begin{array}{l}\text { Gas production, } \\
\mathrm{ml} \cdot \text { day }^{-1}\end{array}$ & $3630.0^{\mathrm{b}, \mathrm{c}, \mathrm{d}}$ & $3341.0^{\mathrm{c}, \mathrm{d}}$ & $3492.0^{\mathrm{d}}$ & 3468.0 & 56.4 \\
\hline $\begin{array}{l}\mathrm{H}_{2} \text { production, } \\
\mathrm{mM} \cdot \text { day }^{-1}\end{array}$ & 80.52 & 74.91 & 83.49 & 75.75 & 2.1 \\
\hline $\begin{array}{l}\mathrm{H}_{2} \text { utilization, } \\
\mathrm{mM} \cdot \text { day }^{-1}\end{array}$ & 26.36 & 30.81 & 28.87 & 31.32 & 1.4 \\
\hline \multirow[t]{2}{*}{$\mathrm{H}_{2}$ recovery, $\%$} & $32.75^{\mathrm{b}, \mathrm{c}, \mathrm{d}}$ & $41.16^{\mathrm{c}}$ & 34.74 & 41.27 & 1.3 \\
\hline & \multicolumn{5}{|c|}{$60 \%$ fresh lucerne $+40 \%$ maize (experiment II) } \\
\hline $\begin{array}{l}\text { Gas production, } \\
\mathrm{ml} \cdot \text { day }^{-1}\end{array}$ & 3871.0 & 3698.0 & 3770.0 & 3701.0 & 48.2 \\
\hline $\begin{array}{l}\mathrm{H}_{2} \text { production, } \\
\mathrm{mM} \cdot \text { day }^{-1}\end{array}$ & 88.32 & 82.48 & 87.64 & 81.76 & 2.3 \\
\hline $\begin{array}{l}\mathrm{H}_{2} \text { utilization, } \\
\mathrm{mM} \cdot \text { day }^{-1}\end{array}$ & $29.31^{\mathrm{b}}$ & $36.22^{\mathrm{c}}$ & 29.88 & 32.16 & 1.5 \\
\hline \multirow[t]{2}{*}{$\mathrm{H}_{2}$ recovery, $\%$} & $32.16^{\mathrm{b}, \mathrm{d}}$ & $44.03^{\mathrm{c}, \mathrm{d}}$ & $34.14^{\mathrm{d}}$ & 39.65 & 1.42 \\
\hline & \multicolumn{5}{|c|}{$40 \%$ fresh lucerne and $60 \%$ maize (experiment III) } \\
\hline $\begin{array}{l}\text { Gas production, } \\
\mathrm{ml} \cdot \text { day }^{-1}\end{array}$ & 3330.0 & 3597.0 & 3683.0 & 3416.0 & 36.8 \\
\hline $\begin{array}{l}\mathrm{H}_{2} \text { production, } \\
\mathrm{mM} \cdot \text { day }^{-1}\end{array}$ & 77.65 & 77.75 & 84.69 & 74.09 & 2.2 \\
\hline $\begin{array}{l}\mathrm{H}_{2} \text { utilization, } \\
\mathrm{mM} \cdot \text { day }^{-1}\end{array}$ & 26.23 & 32.10 & 29.49 & 26.86 & 1.1 \\
\hline \multirow[t]{2}{*}{$\mathrm{H}_{2}$ recovery, $\%$} & 33.8 & $40.94^{\mathrm{a}, \mathrm{d}}$ & $34.76^{b}$ & 36.42 & 1.3 \\
\hline & \multicolumn{5}{|c|}{$40 \%$ fresh lucerne and $60 \%$ maize (experiment IV) } \\
\hline $\begin{array}{l}\text { Gas production, } \\
\mathrm{ml} \cdot \text { day }^{-1}\end{array}$ & 3754.0 & 3522.0 & 3741.0 & 3649.0 & 39.7 \\
\hline $\begin{array}{c}\mathrm{H}_{2} \text { production, } \\
\mathrm{mM} \cdot \text { day }^{-1}\end{array}$ & $95.71^{\mathrm{b}}$ & 79.13 & 86.20 & 88.84 & 2.30 \\
\hline $\begin{array}{l}\mathrm{H}_{2} \text { utilization, } \\
\mathrm{mM} \cdot \text { day }^{-1}\end{array}$ & 33.16 & 32.82 & 35.21 & 32.07 & 1.20 \\
\hline $\mathrm{H}_{2}$ recovery, $\%$ & $34.59^{\mathrm{b}, \mathrm{c}}$ & $41.62^{\mathrm{d}}$ & 40.89 & $36.09^{\mathrm{c}}$ & 1.60 \\
\hline
\end{tabular}

LO - linseed oil; RO - rapeseed oil; FO - fish oil

values in a row with different superscripts $\left({ }^{\mathrm{a}, \mathrm{b}, \mathrm{c}, \mathrm{d}}\right)$ differ at $\mathrm{P}<0.05$

also be used during synthesis of volatile fatty acids or incorporated into microbial organic matter (Moss et al., 2000). The principle sources of hydrogen are bacteria and protozoa producing acetic acid (Hegarty and Gerdes, 1998). Hydrogen is a waste fermentation product and when accumulated, rumen digestion is suppressed (Wolin et al., 1997). In the present study, production of metabolic hydrogen was affected only in experiment IV after applying oil blends (LO+RO). With respect to hydrogen utilization during fermentation, it was significantly increased only in experiment II with LO (about 7 percentage units). In general, the recovery of metabolic hydrogen significantly increased with LO, RO, FO (experiment I), LO, FO (experiment II), LO (experiment III), and LO+RO, LO+FO (experiment IV). 
Our previous study also showed a significant increase in hydrogen recovery when microbial oil was used (Jalč and Cĕrtic, 2005). According to Demeyer et al. (1995), other hydrogen acceptors have to be considered in order to explain the lower hydrogen recovery, which also was observed when rapeseed and linseed oils were examined (Machmüller et al., 1998).

\section{CONCLUSIONS}

Total gas production was significantly reduced in a forage diet by LO, RO, and $\mathrm{FO}$, while these oils and their blends ( $\mathrm{LO}+\mathrm{RO}, \mathrm{LO}+\mathrm{FO}, \mathrm{LO}+\mathrm{FO}+\mathrm{RO})$ added to diets having different forage-to-concentrate ratios did not affect total gas release. The production and utilization of metabolic hydrogen were not affected by oils or their blends, however, the recovery of metabolic hydrogen was decreased mainly with $\mathrm{LO}, \mathrm{FO}$, and oil blends (LO+RO, LO+FO).

\section{REFERENCES}

Chai W.Z., van Gelder A.H., Cone J.W., 2004. Relationship between gas production and starch degradation in feed samples. Anim. Feed Sci. Tech. 114, 195-204

Czerkawski J.W., 1986. Introduction to Rumen Studies. Pergamon Press, Oxford, pp. 236

Demeyer D.I., 1991. Quantitative aspects of microbial metabolism in the rumen and hindgut. In: J.P. Jouany (Editor). Rumen Microbial Metabolism and Ruminant Digestion. INRA, Paris, pp. 217-237

Demeyer D. I., Van de Voestyne M., Prins R., 1995. Mikrobiology der Verdauung. In: H. Abel, G. Flachowski, H. Jeroch, S. Molnar (Editors). Nutztierernährung, Potentiale-VerantwortungPerspektiven. Gustav Fisher Verlag, Jena, pp. 185-206

Getachew G., DePeters E.J., Robinson P.H., Taylor S.J., 2001. In vitro rumen fermentation and gas production: influence of yellow grease, tallow, corn oil and their potassium soaps. Anim. Feed Sci. Tech. 93, 1-15

Hegarty R., Gerdes R., 1998. Hydrogen production and transfer in the rumen. In: P.C. Garnsworthy, J. Wiseman (Editors). Recent Advances of Animal Nutrition 12, pp. 37-44

Jalč D., Cěrtic M., 2005. Effect of microbial, monensin and fumarate on rumen fermentation in artificial rumen. Czech. J. Anim. Sci. 10, 467-472

Jalč D., Potkański A., Szumacher-Strabel M., Kowalczyk J., Cieślak A., 2006a. Effect of forage diet and different fat sources on rumen fermentation in vitro. J. Anim. Feed Sci. 15, Suppl. 1, 129-134

Machmüller A., Ossowski D.A., Wanner M., Kreuzer M., 1998. Potential of various fatty feeds to reduce methane release from rumen fermentation in vitro (Rusitec). Anim. Feed Sci. Tech. 71, $117-130$

Moss A.R., Jouany J.P., Newbold C.J., 2000. Methane production by ruminants: its contribution to global warming. Ann. Zootech. 49, 231-253

Wolin M.J., Miller T.L., Stewart C.S., 1997. Microbe-microbe interactions. In: P.N. Hobson, C.S. Stewart (Editors). The Rumen Microbial Ecosystem. 2nd Edition. Blackie Academic and Professional, pp. 475-491 